\title{
Influence of head posture on the visual acuity of children with nystagmus
}

\section{Influência da postura da cabeça na acuidade visual de crianças com nistagmo}

\author{
Ana Carla Ramos Vieira da Costa ${ }^{1}$, Márcia Caires Bestilleiro Lopes $^{2}$, Célia Regina Nakanami ${ }^{3}$
}

\begin{abstract}
Purpose: Evaluate the relationship between the postural alignment of the head and possible interference in the view of children.

Methods: We evaluated 11 children between 2 and 7 years of age of both sexes, with the visually impaired, who had nystagmus and head lock position. The test Lea Grating Acuity Test ${ }^{\circledR}$ was used to collect measurements of visual acuity. This applied on two occasions: with and without postural alignment of the head. For reliability of the postural alignment of the head, the slopes were measured by Fisiologic ${ }^{\circledR}$ software.

Results: The children had a poorer performance after physiological postural alignment. This poor performance is possible due to loss of position lock nystagmus to gain postural alignment, said to be ideal. Postural compensations were observed, and sharply increased eyestrain.
\end{abstract}

Conclusion: The pursuit of traditional postural alignment affect the visual response of children with visual impairments.

Keywords: Posture; Head; Ocular motility disorders; Nystagmus, physiologic; Visual acuity

\section{RESUMO}

Objetivo: Avaliar a relação entre o alinhamento postural da cabeça e a possível interferência na visão de crianças.

Métodos: Foram avaliadas 11 crianças, entre 2 e 7 anos de idade de ambos os sexos, com o diagnóstico de deficiência visual, que apresentavam nistagmo e posição de bloqueio de cabeça. Oteste Lea Grating Acuity Test ${ }^{\circledR}$ foi utilizado para coletarmedidas de acuidadevisual. Este aplicado em dois momentos: sem e com o alinhamento postural da cabeça. Para confiabilidade do alinhamento postural da cabeça, as inclinações foram medidas pelo software Fisiologic ${ }^{\circledR}$.

Resultados: As crianças apresentaram pior desempenho após o alinhamento postural fisiológico. Este pior desempenho é possível devido à perda da posição de bloqueio do nistagmo para ganho do alinhamento postural, dito como ideal. Foram observadas compensações posturais e maior esforço visual.

Conclusão: A busca do alinhamento postural tradicional prejudica a resposta visual de criança com deficiência visual.

Descritores: Postura; Cabeça; Transtornos da motilidade ocular; Nistagmo fisiológico; Acuidade visual

\section{INTRODUCTION}

Vision is a complex process. It allows individuals the experience of shapes and colors as well as the perception of the surrounding environment. It allows an immediate assessment of the elements that stimulate the curiosity and interest of children and plays an important role in image synthesis and formation ${ }^{(1)}$. Vision is not an isolated process. It is integrated with a child's neuropsychomotor development, which includes the development of head posture ${ }^{(2)}$.

For an effective eye gaze, the visual fixation of an object should be sustained on the foveal zone for at least $3 \mathrm{~s}$. Visual fixation is the result of a series of movements, such as saccades, which focus the object of interest in the fovea and move the eyes from one object to another. Fixation can occur either voluntarily or as a reflex, similar to visual pursuit, which is characterized by slow and smooth ocular movements. The main function of visual pursuit is to track the visual stimulus and maintain it near the fovea ${ }^{(3)}$.
Effective visual fixation is necessary for good visual acuity. Visual acuity is a quantitative assessment of the ability of the human sensory system to discriminate detail in objects ${ }^{(4)}$.

The close association between visual acuity and nystagmus has been reported in the literature ${ }^{(5-9)}$. Nystagmus comprises involuntary ocular oscillations that prevent the adequate projection of the image on the retina ${ }^{(5)}$. In nystagmus, saccadic movements hinder foveal fixation, leading to the impairment of visual acuity ${ }^{(6,7)}$.

In congenital nystagmus, which has its onset between either 2 and 3 months or 6 and 12 months of age, visual fixation is possible with a head posture that minimizes nystagmus. At this stage, compensatory movements of the head in the so-called "null position" can occur ${ }^{(10)}$.

Abnormal head positioning implies that this posture is adopted to achieve visual adaptation. In addition, the null position is a habit, and not the cause of nystagmus. It promotes ocular stability and is naturally adopted by children with visual impairment ${ }^{(11)}$. 
There is no scientific evidence that the correct postural alignment of the head in children with nystagmus can improve visual acuity. Most physical therapists believe that the alignment of the head in a position perpendicular to the ground is more important than the compensatory null position adopted by children with nystagmus. Professionals who specialize in visual impairment believe that recovered vision can improve the child's functional performance, consequently improving the quality of life ${ }^{(12)}$.

\section{METHODS}

This prospective, cross-sectional study was conducted between May and November 2010 at the Department of Ophthalmology of the Federal University of São Paulo, Sector of Low Vision and Visual Rehabilitation-Outpatient clinic for Early Visual Stimulation, in collaboration with the University of Santo Amaro.

Eleven male and female children with nystagmus and null head positions were evaluated. The subjects were aged between 2 and 7 years (mean $4.3 \pm 1.4$ ), did not exhibit delayed neuropsychomotor development and/or other associated systemic diseases. In addition, some had developed the ability to speak and could maintain the standing position required to perform the Lea Grating Acuity Test ${ }^{\oplus}$.

The psychophysical Lea Grating Acuity Test ${ }^{\oplus}$ Model 251300 (Figure 1) was used. In this test, the child detects and directs the gaze toward discs with or without a high visual contrast. The equipment includes four discs with plain gray color on one side and black and white parallel lines on the other, which had the following spatial frequencies: 0.5 cycle per degree of visual angle (cpd), $2 \mathrm{cpd}, 4 \mathrm{cpd}$, and $8 \mathrm{cpd}$. The discs are $20 \mathrm{~cm}$ in diameter and both the patterned and the gray side are shown simultaneously to the children. The aim of the test is to determine the number of discs the child is able to identify ${ }^{(13)}$. The assessment of visual acuity and head posture was performed on the same day and on two separate occasions, with and without the correct postural alignment of the head.

Children stood $30 \mathrm{~cm}$ away from the plumb line, with the ear lobes and the right and left acromion visible. The discs were maintained at a distance of $50 \mathrm{~cm}$ from the child. The camera was placed on a tripod, at a height of $80 \mathrm{~cm}$ and a distance of $80 \mathrm{~cm}$ from the plumb line, for the recording of measurements (Figure 2). Using the anterior view, we recorded the head position that blocked nystagmus and the subsequent inclination angles of the head during the performance of the Lea Grating Acuity Test ${ }^{\circledast}$.

The test was performed on a second occasion, after postural alignment of the head (by vertically aligning the child's head); the head posture was aligned manually by the physical therapist and the child's caregiver, and the distance parameters applied were the same as those used during the test performed without the correct postural alignment of the head.

For quantitative analysis of the head posture, the images were analyzed using the Fisiologic ${ }^{\circledast}$ software; the highlighted points were defined and the angles formed between the anatomical points on the trunk and the vertical position of the head were recorded for comparison between the two test situations, and therefore improving data validity (Figure 3).

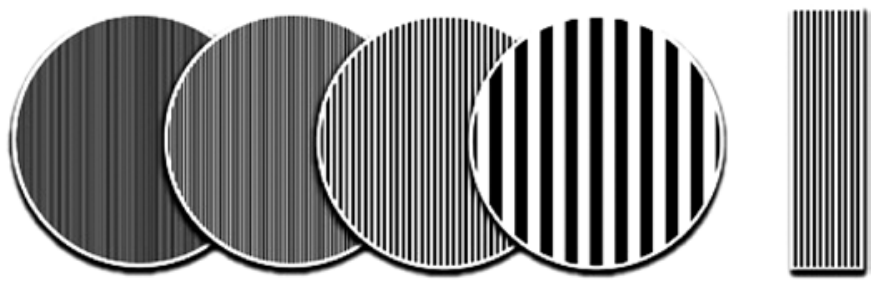

Figure 1. Lea Grating Acuity Test ${ }^{\oplus}$ Model $251300^{(13)}$.

\section{RESULTS}

Three of the 11 children detected all four discs in the nystagmus null position. However, these children detected only two discs after the correct postural alignment of the head. In addition, three children detected three discs in the nystagmus null position, but only one disc after the correct postural alignment of the head.
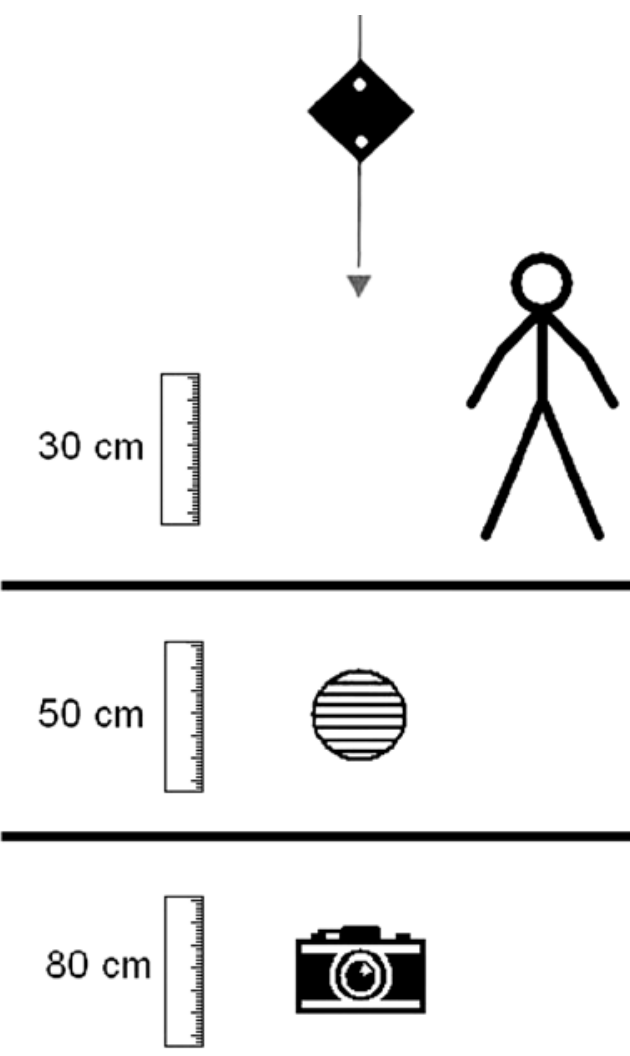

Measureents

$30 \mathrm{~cm}$ : Plumb line/Child

$50 \mathrm{~cm}$ : Plumb line/Lea Grating Acuity Test

$80 \mathrm{~cm}$ : Plumb line - Camera

Figure 2. Scheme of the positioning of the equipment and measurements for test presentation.

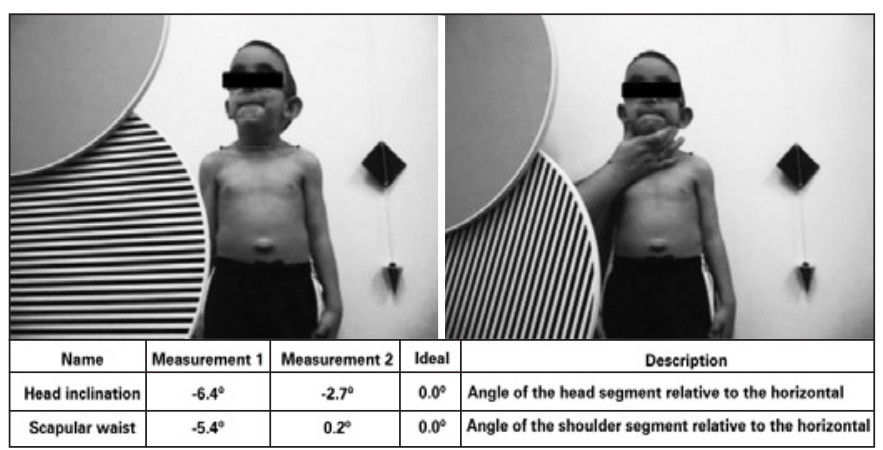

Figure 3. Example of evaluation and variability of postural alignment. 
Three children detected three discs in the null position and later detected only two discs after the correct postural alignment of the head.

Two children detected the same number of discs in the nystagmus null position and following the postural alignment of the head. One child detected all four discs in both head postures and another detected two discs in both postures.

These data were used to determine the ideal head posture to be adopted during rehabilitation treatment. According to the results obtained, the children had worse performance after the correct postural alignment of the head, as shown in graph 1.

Table 1 shows the number of discs detected per child in the null position and in the correct postural alignment of the head. There was a significant difference between the two conditions, with a Z score of -2.76 and a $p$ value of $0.006^{*}(p<0.05)$, indicating that the children detected more discs in the null position than in the correct postural alignment of the head.

Table 2 shows the variations in postural alignment the head and scapular waist in both conditions. Six children exhibited significantly poorer alignment of the scapular waist after postural alignment of the head. Five children exhibited improved alignment of the scapular waist following postural alignment of the head. Notably, alignment improvement was subtle in most children.

\section{DISCUSSION}

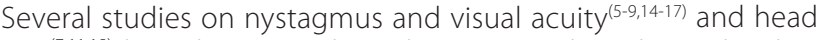
posture ${ }^{(7,11,18)}$ have been conducted. However, the relationship between head posture and visual acuity has not been fully explored ${ }^{(7-9,11)}$.

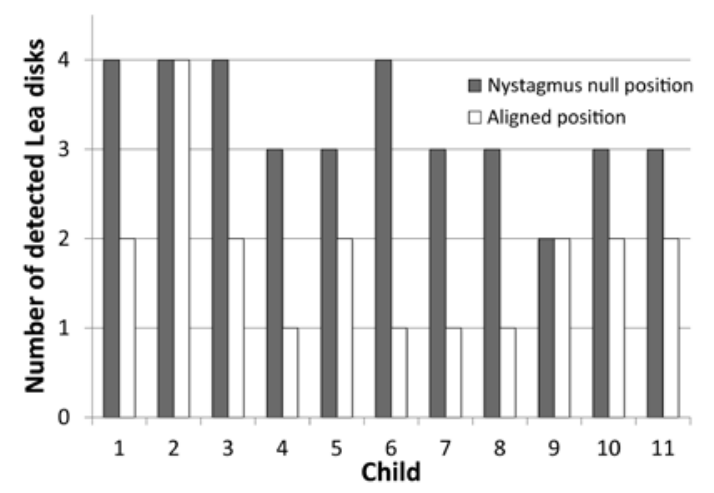

Graph 1. Representation of the visual performance on the two occasions: null and aligned positions.

Table 1. Results of the Lea Grating Acuity Test ${ }^{\circledR}$ in two situations: null position and head alignment

\begin{tabular}{ccc}
\hline Children & Null position & Aligned position* \\
\hline 1 & 4 & 2 \\
2 & 4 & 2 \\
3 & 4 & 4 \\
4 & 3 & 2 \\
5 & 3 & 1 \\
6 & 4 & 2 \\
7 & 3 & 1 \\
8 & 3 & 1 \\
9 & 2 & 2 \\
10 & 3 & 2 \\
11 & 3 & 2 \\
\hline
\end{tabular}

The alignment of head posture in children with nystagmus greatly influences visual acuity. In the nystagmus null position, ocular movements are blocked or minimized, allowing the object to be directly focused on the foveal center, consequently improving visual acuity. In the correct postural alignment of the head, nystagmus is neither blocked nor minimized, resulting in an increase in the frequency and amplitude of ocular movement, leading to lower visual acuity ${ }^{(5-7,10)}$.

According to the results obtained in this study, nine children detected more discs in the nystagmus null position than in the aligned head posture. This better performance is probably the result of image fixation at the foveal center for a longer period in the null position, thereby promoting better visual acuity ${ }^{(6)}$.

On the other hand, in the correct postural alignment of the head, images are not directed to the foveal center, resulting in low visual acuity ${ }^{(6,7)}$. We observed that the nystagmus worsened in seven children under these conditions.

Two children could detect the same number of discs in both head postures; however, during the test, one of the children made a greater effort to focus on the discs, with increased eyelid aperture.

Vision was compromised in most children when the scapular waist was compensated. Therefore, physiological postural alignment of the head through traditional physical therapy not only hinders visual performance but also causes skeletal muscle compensation in more stable areas of the body (e.g., the scapular waist), considering that the head is part of the axial skeleton, although very mobile.

Conditions such as neck deformities by muscle shortening can occur over time, through sustained null position for long periods. In such situations, the term torticollis is more appropriate; however, it is a consequence and not the cause of the null position ${ }^{(11)}$.

Several surgical procedures are available for nystagmus treatment, with a view for eliminating the abnormal head posture. If nystagmus is accompanied with strabismus, surgery should simultaneously correct both the abnormal head posture and ocular deviation. We believe that surgical procedures intended to maintain the rotation angle of the head between the postural deviation of the head and the null area, can both eliminate the incorrect head posture and restore visual acuity at the correct ocular position ${ }^{(8,9)}$

Other treatment options for nystagmus include injections of botulinum toxin in the extraocular muscles or the retrobulbar space. Moreover, electro-optical devices are currently being developed as a noninvasive method to eliminate the visual consequences of nystagmus. In this sense, the subject looks through a telescope associated with a sensor that detects ocular movements. The sensor sends a signal to a servomotor that moves the telescope lenses and thereby

Table 2. Description of the variation in postural alignment of the head and nystagmus null position

\begin{tabular}{cccccc}
\hline & \multicolumn{2}{c}{ Head tilt } & & \multicolumn{2}{c}{ Scapular waist } \\
\cline { 2 - 3 } \cline { 5 - 6 } Child & Null position & Aligned position & & Null position & Aligned position \\
\hline 1 & $-6.4^{\circ}$ & $-2.7^{\circ}$ & & $-5.4^{\circ}$ & $0.2^{\circ}$ \\
2 & $-6.1^{\circ}$ & $3.4^{\circ}$ & & $-5.5^{\circ}$ & $-3.2^{\circ}$ \\
3 & $15.6^{\circ}$ & $-3.3^{\circ}$ & & $-3.1^{\circ}$ & $-5.0^{\circ}$ \\
4 & $3.9^{\circ}$ & $-2.0^{\circ}$ & & $-6.6^{\circ}$ & $-11.7^{\circ}$ \\
5 & $-13.0^{\circ}$ & $-2.9^{\circ}$ & & $0.5^{\circ}$ & $-8.9^{\circ}$ \\
6 & $-17.9^{\circ}$ & $-1.8^{\circ}$ & & $-5.4^{\circ}$ & $5.2^{\circ}$ \\
7 & $16.7^{\circ}$ & $1.3^{\circ}$ & & $8.2^{\circ}$ & $0.8^{\circ}$ \\
8 & $5.6^{\circ}$ & $-2.8^{\circ}$ & & $-4.5^{\circ}$ & $-3.6^{\circ}$ \\
9 & $3.9^{\circ}$ & $-0.9^{\circ}$ & & $-12.2^{\circ}$ & $-7.3^{\circ}$ \\
10 & $4.2^{\circ}$ & $-0.5^{\circ}$ & & $-5.3^{\circ}$ & $-9.0^{\circ}$ \\
11 & $-4.6^{\circ}$ & $0.0^{\circ}$ & & $12.7^{\circ}$ & $-6.7^{\circ}$ \\
\hline
\end{tabular}


abolishes the visual limitation of nystagmus. However, such electrooptical devices are not yet commercially available ${ }^{(9)}$.

Families of children with nystagmus should be advised to find outpatient care centers specializing in low vision to correct the null position, which interferes with child development, and to prevent the impairment of visual performance. Therefore, specialists in visual impairment should manage both head posture conditions to ensure that the child is not adversely affected.

In the opinion of physical therapists specialized in visual impairment, a better visual acuity leads to improved functional performance of the child, consequently providing an improved quality of life ${ }^{(12)}$. In this study, we suggest that visual performance should be contemplated in the rehabilitation of children with visual impairment with an aim to assess better head postures and to avoid the adoption of a stable head posture, thereby preventing muscle shortening and body compensations and improving visual acuity.

\section{CONCLUSION}

This study assessed the influence of the postural alignment of the head on visual acuity in children with nystagmus. We observed that postural alignment of the head had a positive effect on the control of nystagmus. On the other hand, the physiological alignment in children with nystagmus did not result in good visual performance.

\section{REFERENCES}

1. Padula WV, Spungin SS. A criança visualmente incapacitada, do nascimento até a idade pré-escolar: a importância da estimulação visual. Rev Benjamin Constant. 2000;6(16):10-3. 2. Bower TG. The visual world of infants. Sci Am. 1966;215(6):80-92

3. Kanski JJ. Oftalmologia Clínica: uma abordagem sistemática. 6a ed. Rio de Janeiro: Elsevier; 2008.
4. Bicas HE. Acuidade visual: medidas e notações. Arq Bras Oftalmol. 2002;65(3):375-84. 5. Weiss HA, Kelly PJ. Acuity development in infantile nystagmus. Invest Ophthalmol Vis Sci. 2007;48(9):4093-9.

6. Vaunghan D, Asbury T, Riodan-Eva P. Oftalmologia Geral. 15a ed. São Paulo: Atheneu; 2008.

7. Caovilla HH, Ganança MM, Munhoz MS, Silva MG, Frazza MM. O equilíbrio corporal e os seus distúrbios. Parte l: noções de neuroanatomofisiologia do sistema vestibular. Rev Bras Med Otorrinolaringol. 1997:4(1):11-9.

8. Wang P, Lou L, Song L. Design and efficacy of surgery for horizontal idiopathic nystagmus with abnormal head posture and strabismus. J Huazhong Univ Sci Technolog Med Sci. 2011;31(5):678-81.

9. Thurtell MJ, Leigh RJ. Treatment of nystagmus. Curr Treat Options Neurol. 2012; 14(1):60-72.

10. Cullom DR, Chang B. Manual das doenças oculares "Wills Eye Hospital": diagnóstico e tratamento no consultório e na emergência. 2a ed. Rio de Janeiro: Cultura Médica; 1998.

11. Bicas HE. Torcicolo posição viciosa de cabeça. Medicina (Ribeirão Preto). 2000; 33(1):64-72.

12. Lopes MC, Salomão SR, Berezovsky A, Tartarella MB. [Assessing vision-related quality of life in children with bilateral congenital cataracts]. Arq Bras Oftalmol. 2009; 72(4):467-80. Portuguese.

13. Hyvarinen L. Instruções para o Sistema de Testes Lea. Helsinki, Finland; Goog-Lite; 2012 [cited 2012 Oct 20]. Available from: http://www.lea-test.fi

14. Felius J. Fu VL, Birch EE, Hertle RW, Jost RM, Subramanian V. Quantifying nystagmus in infants and young children: relation between foveation and visual acuity deficit. Invest Ophthalmol Vis Sci. 2011;52(12):8724-31.

15. Han SB, Yang HK, Hyon JK, Seo JM, Lee JH, Lee IB, et al. Efficacy of a computerized optokinetic nystagmus test in prediction of visual acuity of better than 20/200. Invest Ophthalmol Vis Sci. 2011;52(10):7492-7

16. Han SB, Han ER, Hyon JY, Seo JM, Lee JH, Hwang JM. Measurement of distance objective visual acuity with the computerized optokinetic nystagmus test in patients with ocular diseases. Graefes Arch Clin Exp Ophthalmol. 2011;249(9):1379-85.

17. Weiss AH, Kelly JP, Phillips JO. Relationship of slow-phase velocity to visual acuity in infantile nystagmus associated with albinism. J AAPOS. 2011;15(1):33-9. Comment in: J AAPOS. 2011;15(1):1-2.

18. Bunnell WP. Selective screening for scoliosis. Clin Orthop Relat Res. 2005;(434):40-5

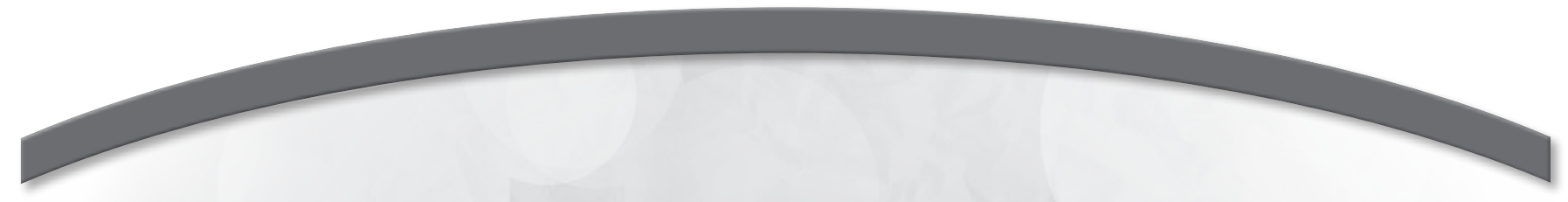

\section{Congresso da Associação Paranaense de Oftalmologia}

\section{2 a 25 de maio de 2014}

\section{Centro de Eventos}

Londrina - PR

Informações:

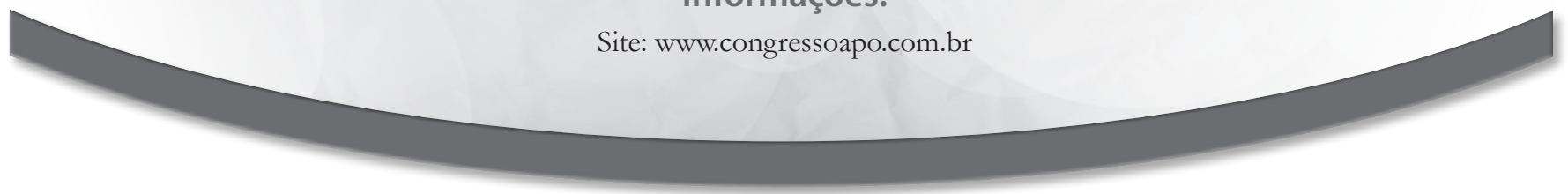

